\section{Loyalitas Kreativitas Aldi Masyarakat Kreatif}

P-ISSN 2722-2101, E-ISSN 2722-4201

Program Studi Ekonomi Manajemen Universitas Pamulang Jurnal

LOKABMAS Kreatif Vol.02,No.02.Juli 2021 Hal.107-114

Email:jurnalkreatif.manajemen@gmail.com

\title{
MANAJEMEN KEWIRAUSAHAAN DAN MENINGKATKAN KUALITAS SUMBER DAYA MANUSIA
}

\author{
Septi Rostika Anjani, Hamdi Supriadi, Neneng Tita Amalya, \\ Endah Mawarny, Ifa Nurmasari \\ Dosen Ekonomi Fakultas Ekonomi Universitas Pamulang \\ Email dosen01699@unpam.ac.id, dosen01021@unpam.ac.id, \\ dosen01751@unpam.ac.id, dosen01747@unpam.ac.id, dosen01550@unpam.ac.id
}

\begin{abstract}
ABSTRAK
Pandemi covid 19 yang melanda bangsa Indonesia bahkan seluruh dunia, sangat mempengaruhi perekonomian. Menurut Badan Pusat Statistik, pada akhir 2020, perekonomian Indonesia mengalami penurunan 2,07 \% dibandingkan tahun 2019. Hal ini tentu saja menimbulkan penurunan kesejahteraan warga Indonesia. Bahkan, tidak sedikit pekerja yang mengalami Pemutusan Hubungan Kerja (PHK). Akhirnya untuk bertahan hidup dan menghidupi keluarga beberapa ibu rumah tangga bekerja apa saja untuk membantu perekonomian keluarga. Berkaitan dengan keadaan ini, maka pengetahuan di bidang kewirausahaan nampaknya dapat menjadi alternatif kaum ibu / bapak yang sampai saat ini usahanya masih serabutan, agar dapat memperoleh penghasilan yang jelas, mapan dan terkelola dengan baik melalui suatu usaha yang menghasilkan produk tertentu di rumah. Salah satu cara untuk mengembangkan perekonomian di Indonesia adalah masyarakat harus merubah pola fikirnya untuk menjadi seorang wirausahaawan.

Pemberdayaan Kesejahteraan Keluarga (PKK) sebagai wadah kegiatan wanita mempunyai peranan dalam membantu program pemerintah melalui gerakannya yang bertujuan mewujudkan keluarga sehat, sejahtera, maju dan mandiri. PKK mempunyai peran yang sangat strategis dalam memberdayakan keluarga terutama perempuan sebagai motor penggeraknya. Pemberdayaan Kesejahteraan Keluarga (PKK) sebagai gerakan pembangunan masyarakat bermula dari seminar Home Economic di Bogor pada 1957. Sebagai tindak lanjut dari seminar tersebut, pada 1961 panitia penyusunan tata susunan pelajaran pada Pendidikan Kesejahteraan Keluarga (PKK), Kementerian Pendidikan bersama kementerian-kementerian lainnya menyusun 10 segi kehidupan keluarga. Gerakan PKK dimasyarakatkan berawal dari kepedulian istri gubernur Jawa Tengah pada 1967 (ibu Isriati Moenadi) setelah melihat keadaan masyarakat yang menderita busung lapar. Upaya untuk meningkatkan kesejahteraan keluarga melalui 10 segi pokok keluarga dengan membentuk Tim Penggerak PKK di semua tingkatan, yang keanggotaan timnya secara relawan dan terdiri dari tokoh/pemuka masyarakat, para isteri kepala dinas/jawatan dan isteri kepala daerah sampai dengan tingkat desa dan kelurahan yang kegiatannya didukung dengan anggaran pendapatan dan belanja daerah.

Tujuan dari kegiatan pengabdian kepada masyarakat (PKM) ini adalah untuk berbagi ilmu, berbagi pengalaman dan menebarkan semangat berwirausaha dari Tim Pengabdian Kepada Masyarakat (PKM) program studi Manajemen, Universitas Pamulang (UNPAM) kepada ibu-ibu PKK kelurahan Kedaung kecamatan Pamulang tentang manajemen berwirausaha dan meningkatkan kualitas SDM di era pandemi seperti saat ini dengan cara
\end{abstract}




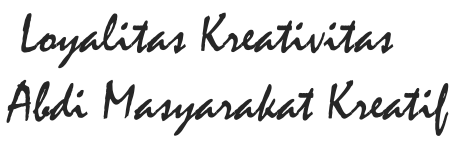

P-ISSN 2722-2101, E-ISSN 2722-4201

Program Studi Ekonomi Manajemen Universitas Pamulang Jurnal LOKABMAS Kreatif Vol.02,No.02.Juli 2021 Hal.107-114

Email:jurnalkreatif.manajemen@gmail.com

meningkatkan pengetahuan dan wawasan akan kewirausahaan beserta proses-prosesnya serta menumbuhkan dan meningkatkan motivasi untuk menjadi wirausaha sukses.

\title{
Kata kunci : Pandemi, PKK, Kewirausahaan
}

\begin{abstract}
The Covid 19 pandemic that hit the Indonesian nation and even the entire world, greatly affected the economy. According to the Central Statistics Agency, at the end of 2020, the Indonesian economy had decreased by 2.07\% compared to 2019. This of course resulted in a decline in the welfare of Indonesians. In fact, not a few workers have experienced layoffs (PHK). Finally, to survive and support the family, some housewives work anything to help the family economy. In connection with this situation, it seems that knowledge in the field of entrepreneurship can be an alternative for mothers / fathers whose business is still odd, in order to obtain a clear, stable and well-managed income through a business that produces certain products at home. One way to develop the economy in Indonesia is that people must change their mindset to become an entrepreneur.

Empowerment of Family Welfare (PKK) as a forum for women's activities has a role in helping government programs through its movement which aims to create a healthy, prosperous, advanced and independent family. PKK has a very strategic role in empowering families, especially women as the driving force. Empowerment of Family Welfare (PKK) as a community development movement originated from the Home Economic seminar in Bogor in 1957. As a follow-up to the seminar, in 1961 the committee for composing lesson structures on Family Welfare Education (PKK), the Ministry of Education together with other ministries compiled 10 facets of family life. The PKK movement was socialized starting from the concern of the wife of the governor of Central Java in 1967 (Mrs. Isriati Moenadi) after seeing the condition of the people who were suffering from edema. Efforts to improve family welfare through the 10 main aspects of the family by forming a PKK Driving Team at all levels, whose team membership is voluntary and consists of community leaders / leaders, wives of the heads of offices / services and wives of regional heads up to the village and sub-district levels whose activities supported by regional revenue and expenditure budgets.

The purpose of this community service (PKM) activity is to share knowledge, share experiences and spread the entrepreneurial spirit of the Community Service Team (PKM) for the Management study program, Pamulang University (UNPAM) to PKK mothers in Kedaung village, Pamulang sub-district about entrepreneurial management. And improving the quality of human resources in the current pandemic era by increasing knowledge and insight into entrepreneurship and its processes as well as growing and increasing motivation to become successful entrepreneurs.
\end{abstract}

\section{Keywords: Pandemic, PKK, Entrepreneurship}

\section{PENDAHULUAN}

Pandemi covid 19 yang melanda bangsa Indonesia bahkan seluruh dunia, sangat mempengaruhi perekonomian. Menurut Badan Pusat Statistik, pada akhir 2020, perekonomian
Indonesia mengalami penurunan 2,07 \% dibandingkan tahun 2019. Hal ini tentu saja menimbulkan penurunan kesejahteraan warga Indonesia. Bahkan, tidak sedikit pekerja yang mengalami Pemutusan Hubungan Kerja (PHK). Akhirnya untuk bertahan hidup dan 


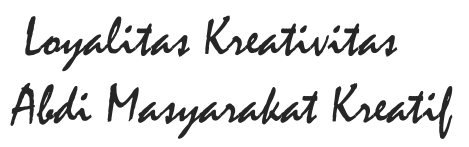

P-ISSN 2722-2101, E-ISSN 2722-4201

Program Studi Ekonomi Manajemen Universitas Pamulang Jurnal LOKABMAS Kreatif Vol.02,No.02.Juli 2021 Hal.107-114

Email:jurnalkreatif.manajemen@gmail.com menghidupi keluarga beberapa ibu rumah tangga bekerja apa saja untuk membantu perekonomian keluarga. Berkaitan dengan keadaan ini, maka pengetahuan di bidang kewirausahaan nampaknya dapat menjadi alternatif kaum ibu / bapak yang sampai saat ini usahanya masih serabutan, agar dapat memperoleh penghasilan yang jelas, mapan dan terkelola dengan baik melalui suatu usaha yang menghasilkan produk tertentu di rumah. Salah satu cara untuk mengembangkan perekonomian di Indonesia adalah masyarakat harus merubah pola fikirnya untuk menjadi seorang wirausahaawan.

Wirausaha adalah orang yang pandai dan berbakat mengenali produk baru yang bermanfaat bagi masyarakat, menentukan cara produksi baru, menyusun operasi (tindakan) untuk pengadaan produk baru, memasarkan, dan mengatur permodalan operasinya. Singkatnya, wirausaha adalah orang yang secara mandiri mengelola seluruh hal-hal yang berkaitan dengan produksi dan penjualan suatu barang yang bermanfaat bagi masyarakat. Di Indonesia, kewirausahaan dipelajari baru terbatas pada beberapa sekolah atau perguruan tinggi tertentu saja. Sejalan dengan perkembangan dan tantangan seperti adanya krisis ekonomi, pemahaman kewirausahaan baik melalui pendidikan formal maupun pelatihan-pelatihan disegala lapisan masyarakat kewirausahaan menjadi berkembang. Orang yang melakukan kegiatan kewirausahaan disebut wirausahawan.

Secara awam, sebelum berwirausaha kita harus mempersiapkan dan merencanakan modal, peralatan yang digunakan untuk produksi, prosedur baku pembuatan barang produksi, bahan baku produk, pemasok bahan baku (kalau baru mulai usaha berarti lokasi pengambilan bahan baku), pelaksana, pemegang keuangan, pelaku pemasaran, menentukan jumlah barang yang akan diproduksi, target penjualan, sasaran konsumen, harga barang produk, keuntungan yang diharapkan, jalan keluar jika mengalami hambatan, sampai hal-hal kecil seperti bentuk kemasan, nama produk dan bentuk label. Setelah semua dipersiapkan, barulah kita memulai bisnis yang tentunya diawali dengan niat dan motivasi yang tinggi, serta doa agar usaha kita berhasil dengan baik. Bukankah kita berusaha, Tuhan jua yang menentukan.

Pemberdayaan Kesejahteraan Keluarga (PKK) sebagai wadah kegiatan wanita mempunyai peranan dalam membantu program pemerintah melalui gerakannya yang bertujuan mewujudkan keluarga sehat, sejahtera, maju dan mandiri. PKK mempunyai peran yang sangat strategis dalam memberdayakan keluarga terutama perempuan sebagai motor penggeraknya. Pemberdayaan Kesejahteraan Keluarga (PKK) sebagai gerakan pembangunan masyarakat bermula dari seminar Home Economic di Bogor pada 1957. Sebagai tindak lanjut dari seminar tersebut, pada 1961 panitia penyusunan tata susunan pelajaran pada Pendidikan Kesejahteraan Keluarga (PKK), Kementerian Pendidikan bersama kementerian-kementerian lainnya menyusun 10 segi kehidupan keluarga. Gerakan PKK dimasyarakatkan berawal dari kepedulian istri gubernur Jawa Tengah pada 1967 (ibu Isriati Moenadi) setelah melihat keadaan masyarakat yang menderita busung lapar. Upaya untuk meningkatkan kesejahteraan keluarga melalui 10 segi pokok keluarga dengan membentuk Tim Penggerak PKK di semua tingkatan yang keanggotaan timnya secara relawan dan terdiri dari tokoh/pemuka masyarakat, para isteri kepala dinas/jawatan dan isteri kepala daerah sampai dengan tingkat desa dan kelurahan yang kegiatannya didukung dengan anggaran pendapatan dan belanja daerah.

\section{RUMUSAN MASALAH}

Berdasarkan pengamatan tersebut, kami dari Tim Program Pengabdian Kepada Masyarakat (PKM) dari Universitas Pamulang (UNPAM) akan mengadakan PKM, yang 
Loyalitas Kreativitas
Aldi Masyarakat Kreatif
P-ISSN 2722-2101, E-ISSN 2722-4201

Program Studi Ekonomi Manajemen Universitas Pamulang Jurnal LOKABMAS Kreatif Vol.02,No.02.Juli 2021 Hal.107-114

Email:jurnalkreatif.manajemen@gmail.com bekerja sama dengan ibu - ibu PKK kelurahan Kedaung kecamatan Pamulang, Tangerang Selatan. PKM ini dilaksanakan dengan memberikan materi tentang bagaimana manajemen kewirausahaan dan meningkatkan kualitas SDM di era pandemi seperti sekarang ini, berbagi pengalaman dan juga memberikan motivasi tentang manajemen wirausaha .

\section{TUJUAN PELAKSANAAN}

Tujuan dari kegiatan pengabdian kepada masyarakat (PKM) ini adalah untuk berbagi ilmu, berbagi pengalaman dan menebarkan semangat berwirausaha dari Tim Pengabdian Kepada Masyarakat (PKM) program studi Manajemen, Universitas Pamulang (UNPAM) kepada ibu-ibu PKK kelurahan Kedaung kecamatan Pamulang tentang manajemen berwirausaha dan meningkatkan kualitas SDM di era pandemi seperti saat ini dengan cara meningkatkan pengetahuan dan wawasan akan kewirausahaan beserta proses-prosesnya. Serta menumbuhkan dan meningkatkan motivasi untuk menjadi wirausaha sukses.

\section{TINJAUAN PUSTAKA}

\section{MANAJEMEN}

Manajemen telah banyak disebut sebagai "seni untuk menyelesaikan pekerjaan melalui orang lain". Defenisi ini yang dekemukakan oleh Mary Parker Follet, mengandung arti bahwa manager mencapai tujuan-tujuan organisasi melalui pengaturan orang lain untuk melaksanakan berbagai pekerjaan yang diperlukan, atau dengan kata lain dengan tidak melakukan pekerjaanpekerjaan itu sendiri. Suatu perusahaan memiliki beragam aktivitas, serta banyaknya sumber daya yang terlibat dan dibutuhkan untuk menjalankan perusahaan tersebut. Oleh karena itu, manajemen yang baik sangat dibutuhkan untuk mengatur serta menjadikan perusahaan tersebut tumbuh dan berkembang sesuai dengan yang diharapkan. Berikut devinisi manajemen menurut beberapa ahli yaitu : Menurut Malayu S.P. Hasibuan (2014:10), manajemen adalah ilmu dan seni mengatur proses pemanfaatan sumber daya manusia dan sumber-sumber lainnya secara efeltif dan efisien untuk mencapai suatu tujuan tertentu.

\section{WIRAUSAHA}

Wirausaha berasal dari dua suku kata, wira dan usaha. Wira mempunyai arti sebagai pejuang, pahlawan, berbudi luhur, manusia unggul, berwatak agung dan gagah berani. Di lain sisi, usaha merupakan sebuah perbuatan atau amalan, berbuat sesuatu dan bekerja. Oleh karena itu, secara harfiah makna dari wirausaha adalah sebuah pejuang dalam melakukan suatu pekerjaan. Menurut Kamus Besar Bahasa Indonesia (KBBI), wirausaha merupakan orang yang pandai atau berbakat da lam memahami produk baru, menentukan cara produksi baru, menyusun operasi untuk mengadakan produk baru hingga mengatur permodalan dan pemasarannya. Melalui beberapa pengertian diatas, kita dapat mengambil kesimpulan bahwa wirausaha merupakan seseorang yang mempunyai kemampuan dalam menciptakan dan menerapkan cara kerja teknologi dan produk baru dengan meningkatkan efisiensi dan memperoleh keuntungan yang sebesarbesarnya.

\section{MENGAPA BERWIRAUSAHA}

Dengan berwirausaha, banyak hal positif yang bisa kita dapatkan, antara lain :

1. Menentukan Penghasilan Sendiri

Ketika berwirausaha, kita menjadi bos atas diri sendiri. Kita tidak perlu menunggu gaji dari orang, tapi kita yang menggaji diri kita sendiri. Ketika ingin hasil yang banyak, maka kita harus bekerja lebih giat. Kita yang menentukan sendiri target pendapatan kita.

2. Mengembangkan Potensi Diri

Jika kita bekerja sebagai karyawan, kita mungkin akan terpaksa mengerjakan apa yang tidak kita pahami. Kita mungkin 
Loyalitas Kreativitas
Aldi Masyarakat Kreatif
P-ISSN 2722-2101, E-ISSN 2722-4201

Program Studi Ekonomi Manajemen Universitas Pamulang Jurnal LOKABMAS Kreatif Vol.02,No.02.Juli 2021 Hal.107-114

Email:jurnalkreatif.manajemen@gmail.com bekerja bukan pada bidang yang paling kita kuasai. Sedangkan jika kita berbisnis sendiri, kita bisa lebih bebas dalam mengeksplorasi dan mengembangkan kemampuan diri. Tidak ada yang menghalangi kita untuk melakukan apapun, kecuali kita sendiri yang tidak mau mencobanya.

\section{Melakukan Apa yang Disukai}

Saat berbisnis, kita punya kesempatan untuk melakukan pekerjaan yang kita sukai. Kita bisa menjalankan usaha yang sesuai hobi dan bersenang-senang sambil menghasilkan uang. Namun, jika kita bekerja dengan orang lain, kita akan dibebankan tugas yang tidak disukai.

\section{Melatih Mental Sebagai Pemimpin}

Sekecil apapun usaha yang kita rintis, kita langsung menjadi seorang pemimpin atas bisnis kita. Kita ini akan melatih mental kepemimpinan. Kita akan belajar banyak hal, mulai dari mengambil keputusan, mendelegasikan pekerjaan, menyelesaikan masalah, dan sebagainya.

\section{Menciptakan Perubahan}

Keuntungan menjadi wirausaha adalah kita berkesempatan untuk menciptakan perubahan. Kita harus bisa berinovasi dan menghadirkan sesuatu yang baru bagi dunia. Contohnya, Facebook mengubah cara kita berinteraksi melalui media sosial. Go-Jek menghadirkan layanan ojek online yang memudahkan masyarakat untuk mencari alat transportasi roda dua

6. Membantu Membuka Lapangan Kerja. Kita berkontribusi dalam mengurangi angka pengangguran. Kita berperan penting untuk membantu masyarakat yang ingin mencari nafkah. Semakin besar bisnis kita, semakin banyak lapangan kerja yang bisa dibuka. Banyak orang yang bisa kita pekerjakan, sehingga hidup kita akan terasa lebih berguna.

7. Wawasan Bertambah Banyak
Jika kita adalah seorang karyawan, setidaknya kita hanya perlu menguasai bidang pekerjaan kita saja. Sedangkan jika kita menjadi wirausaha, mau tak mau kita harus mempelajari banyak hal. Kita harus tahu bagaimana cara memanajemen keuangan, membuat strategi marketing, memimpin anak buah, melayani pelanggan, dan lain-lain. Wawasan kita pasti akan bertambah banyak, karena itulah yang dibutuhkan untuk mengelola bisnis supaya berhasil.

\section{Relasi semakin luas}

Kita akan bertemu dengan banyak orang ketika berbisnis, mulai dari konsumen, sesama pebisnis, investor, sampai aparatur pemerintah. Kita memang memerlukan banyak relasi tersebut. Koneksi kita harus luas agar kita bisa lebih mudah dalam memasarkan produk, mengembangkan bisnis, menjalin kerja sama, dan juga mengurus perizinan usaha

\section{Waktu Lebih Fleksibel}

Memang ada banyak hal yang harus dikerjakan ketika menjalankan bisnis. Namun, bisa dibilang bahwa waktu kita menjadi lebih fleksibel, karena kita sendiri yang menentukan jam kerja kita. Terlebih lagi jika bisnis kita sudah punya sistem yang baik, kita tidak perlu mengawasinya setiap saat. Sebab bisnisnya bisa terus berjalan, walaupun kita sedang tidak berada di tempat usaha atau kantor.

\section{MENINGKATKAN KUALITAS SDM}

Pendidikan harus terus berikhtiar membangun generasi bangsa yang cakap secara intelektual, anggun secara moral, dan siap menghadapi tantangan zamannya. Pendidikan juga harus mampu melahirkan generasi bangsa yang memiliki jiwa dan pikiran besar untuk membangun negerinya. Di sisi lain, yang juga perlu disadari, pendidikan bukan tanggung jawab pemerintah/negara semata. Pendidikan 


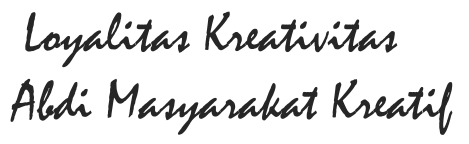

P-ISSN 2722-2101, E-ISSN 2722-4201

Program Studi Ekonomi Manajemen Universitas Pamulang Jurnal LOKABMAS Kreatif Vol.02,No.02.Juli 2021 Hal.107-114

Email:jurnalkreatif.manajemen@gmail.com sebagai jalan kemajuan negeri ini harus menjadi komitmen dan kesadaran bersama.

Menurut Hasibuan (2014:244) sumberdaya manusia adalah kemampuan terpadu dari daya pikir dan daya fisik yang dimiliki individu, Berdasarkan teori diatas maka dapat penulis nyatakan bahwa sumber daya manusia adalah pegawai atau pekerja yang senantiasa rela mencurahkan daya fisik demi tercapainya tujuan-tujuan organisasi. Fakta yang ada memperlihatkan bahwa pendidikan konvensional pada saat ini kurang memberikan kontribusi terhadap pemecahan masalah yang ada malah semakin memperlebar kesenjangan yang ada. Pendidikan luar sekolah merupakan pendidikan alternatif yang dapat memberikan warna baru dalam dunia pendidikan.

\section{METODE PELAKSANAAN}

Pada Kegiatan Pengabdian Kepada Masyarakat kali ini, akan dilakukan dengan memberikan materi mengenai "Manajemen Kewirausahaan dan Meningkatkan SDM". Di sini narasumber akan melakukan berbagi ilmu dan pengalaman kepada warga khususnya ibuibu PKK Kelurahan Kedaung Kecamatan Pamulang sesuai dengan tema tersebut di atas. Materi akan disampaikan dengan komunikatif sehingga pesan yang ingin disampaikan dapat diterima dengan baik.

$$
\text { Kegiatan Pengabdian Kepada }
$$
Masyarakat ini ditujukan untuk 20 ibu-ibu PKK (Pemberdayaan Kesejahteraan Keluarga) Kelurahan Kedaung Kecamatan Pamulang. Dimana ibu-ibu diberikan materi tentang kewirausahaan agar dapat membantu perekonomian keluarga. Adapun pelaksanaan pengabdian masyarakat ini diselenggarakan pada Hari Kamis sampai dengan Sabtu, tanggal 1-3 April 2021. Kegiatan ini dilaksanakan pada pagi hari dari pukul 09.00 sampai dengan pukul 12.00 WIB. Acara ini dilaksanakan di Masjid Al Amien Kelurahan Kedaung Kecamatan Pamulang. Kegiatan ini dilaksanakan dengan tetap mematuhi protokol Kesehatan, yaitu memakai masker dan menjaga jarak selama pelaksanaan.

\section{HASIL DAN PEMBAHASAN}

Sebelum pelaksanaan acara Pengabdian Kepada Masyarakat oleh tim dosen Fakultas Ekonomi, Program Studi Manajemen, Universitas Pamulang di Masjid Al Amien, Kelurahan Kedaung Kecamatan Pamulang, Kota Tangerang Selatan, dilakukan, tim dosen yang terlibat telah melakukan beberapa rangkaian agenda kegiatan sebelum acara pelaksanaan dilakukan. Berikut tahapannya :

1. Kegiatan diawali dengan dilakukannya rapat melalui ZOOM pada hari Kamis, 01 April 2021.

2. Setelah terbentuk susunan panitian dilakukan penyusunan proposal kegiatan yang diajukan pada hari Sabtu tanggal 3 April 2021 dan mendapat persetujuan dari Lembaga Penelitian dan Pengabdian Kepada Masyarakat Universitas Pamulang (LPPM UNPAM)

3. Persiapan acara, dilakukan pukul 08.00 wib. untuk memastikan segala sarana yang dapat menunjang kegiatan telah disiapkan dengan baik. Permasalahan seputar sarana dan prasana dapat diminimalkan dengan saling berkerja sama antar panitia dalam mempersiapkan kegiatan.

4. Registrasi peserta, dilakukan secara offline. di lokasi kegiatan yaitu masjid Al Amin Kelurahan Kedaung.

5. Pembukaan acara dan pembacaan ayat suci Al Quran

Acara dibuka oleh MC yaitu Ibu Neneng Tita Amalya, S.E. , M.Ak, dilanjutkan dengan pembacaan ayat suci Al Quran oleh Abu Rian untuk menambah khitmat acara.

6. Sambutan diberikan oleh Ketua PKK kelurahan Kedaung ( Ibu Turipah ) Dalam sambutannya, beliau menyampaikan ucapan terimakasih kepada dosen UNPAM yang mengadakan acara PKM ini, berbagi ilmu, pengalaman dan motivasi tentang 


\section{Loyalitas Kreativitas Aldi Masyarakat Kreatif}

P-ISSN 2722-2101, E-ISSN 2722-4201

Program Studi Ekonomi Manajemen Universitas Pamulang Jurnal LOKABMAS Kreatif Vol.02,No.02.Juli 2021 Hal.107-114

Email:jurnalkreatif.manajemen@gmail.com bagaimana menjadi enterprener yang sukses.

7. Sambutan dari Ketua PKM, Kegiatan Pengabdian Kepada Masyarakat ini merupakan bagian dari pengamalan Tri Dharma Perguruan Tinggi. Ketua pelaksana PKM, yaitu Ibu Septi Rostika Anjani, S.Pd., M.Sc. mengucapkan terimakasih kepada pihak ibu-ibu PKK keluarahan Kedaung, Kecamatan Pamulang, karena diijinkan untuk mengadakan kegiatan PKM di daerah tersebut. Selain itu, kegiatan ini diharapkan dapat memberikan manfaat kepada ibu-ibu PKK di sana agar dapat menjadi enterprener bagi yang belum, dan menjadi enterprener semakin sukses bagi yang sudah menjalankan usaha.

8. Penyampaian Materi, Sebelum pembicara menyampaikan materi, untuk lebih mengenal pembicara maka dibacakan biodatanya terlebih dahulu. Setelah disampaikan materi oleh Bapak Hamdi Supriadi, S.HI., M.M. diadakan sesi tanya jawab. Ada 3 penanya yang menyampaikan pertanyaan dengan dipandu oleh mahasiswa. Kemudian pertanyaan dijawab langsung oleh pemateri.

9.Penyerahan sourvernir / cinderamata, yang telah disiapkan

oleh dosen Universitas Pamulang dan diberikan kepada ketua Ibu PKK Kelurahan Kedaung, Kecamatan Pamulang. dalam penyelanggaraan kegiatan PKM ini diwakilkan oleh Bapak Hamdi.

10. Penutupan dan pembacaan doa penutup Pada pukul 11.30 acara ditutup dan dilanjutkan dengan doa bersama sebagai rasa syukur atas pelaksanaan acara yang berjalan lancar dan harapan semoga materi yang telah disampaikan pada acara tersebut dapat bermanfaat bagi peserta dan panitia.

11. Foto bersama antara dosen UNPAM dan ibu-ibu PKK Kelurahan Dokumentasi ini penting dilakukan sebagai rekam jejak untuk laporan Pengabdian Kepada Masyarakat UNPAM. Foto Bersama ini dilakukan baik secara offline.
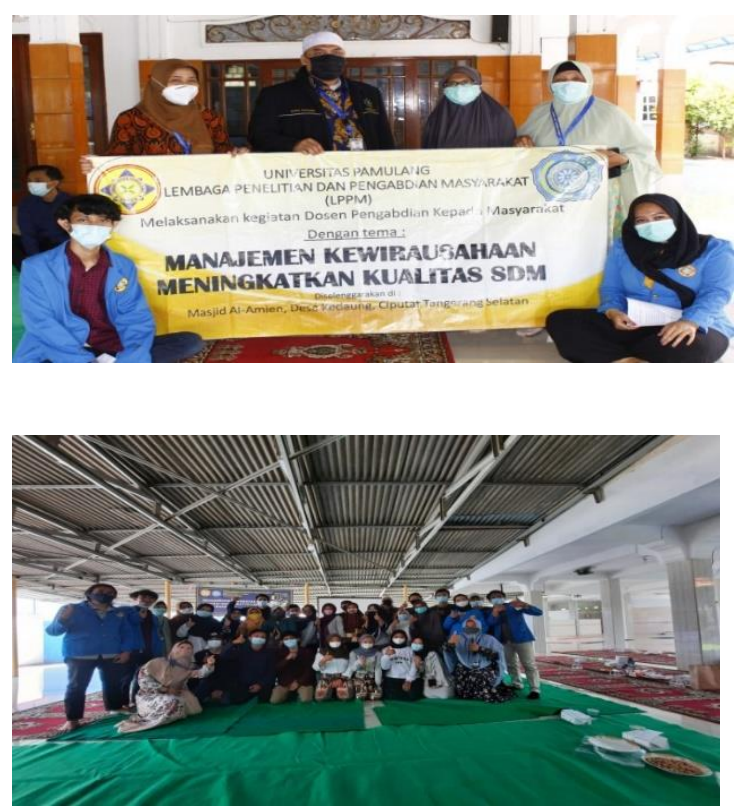

Pada hari ketiga kegiatan PKM, yaitu setelah dilakukan kegiatan inti PKM, dilakukan evaluasi tentang kegiatan yang telah dilaksanakan. Panitia mendatangi kediaman Ibu Turipah selaku Ketua PKK di jalan Wahid, Kelurahan Kedaung, Kecamatan Pamulang, Tangsel.

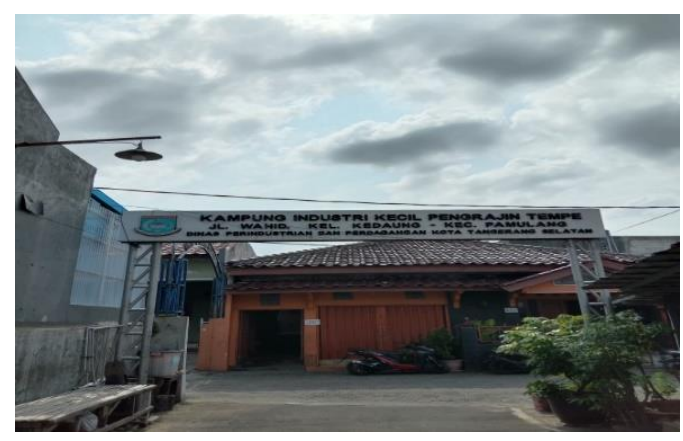

\section{KESIMPULAN DAN SARAN}

KESIMPULAN

Berdasarkan pelaksanaan kegiatan Pengabdian Kepada Masyarakat yang dilaksanakan pada hari Hari Kamis sampai 


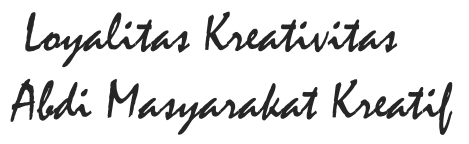

P-ISSN 2722-2101, E-ISSN 2722-4201

Program Studi Ekonomi Manajemen Universitas Pamulang Jurnal LOKABMAS Kreatif Vol.02,No.02.Juli 2021 Hal.107-114

Email:jurnalkreatif.manajemen@gmail.com dengan Sabtu, tanggal 1-3 April 2021. Kegiatan ini dilaksanakan pada pagi hari dari pukul 09.00 sampai dengan pukul 12.00 WIB. Acara ini dilaksanakan di Masjid Al Amien Kelurahan Kedaung Kecamatan Pamulang. dapat diambil kesimpulan bahwa :

1. Secara umum kegiatan Pengabdian Kepada Masyarakat dapat terlaksana dengan baik dan mendapat dukungan dari pihak ibu-ibu PKK Keluhahan Kedaung

2. Materi yang disampaikan oleh narasumber bermanfaat bagi ibu-ibu PKK Keluhahan Kedaung.

\section{SARAN}

Berdasarkan kegiatan yang sudah terlaksana, maka kami memberikan saran sebagai berikut

1. Sebaiknya seorang wirausaha dapat menyesuaikan diri dengan keadaan yang terjadi meskipun dalam kondisi pandemi Covid 19. Selain itu seorang enterpreneur harus dapat memanfaatkan teknologi yang semakin maju untuk membantu dalam proses pemasarannya.

2. Seorang entrepreneur sebaiknya selalu mengikuti pelatihan dan seminar untuk selalu memperbarui pengetahuan yang dimilikinya.

3. Perlu dilakukan kerjasama lebih lanjut antara UNPAM dan ibu-ibu PKK Kelurahan Kedaung

\section{DAFTAR PUSTAKA}

Mawarny, E., Nurmasari, I., Anjani, S. R., Amalya, N. T., \& Supriadi, H. (2021). MANAJEMEN MERAIH SUKSES SEJATI DENGAN BERWIRAUSAHA DI ERA PANDEMI PADA IBU-IBU PKK RT 02 RW 04 RANGKAPAN JAYA BARU DEPOK. Jurnal Abdimas Tri Dharma Manajemen, 2(1), 54-60.

Nurmasari, I., Supriadi, H., Mawarny, E., Amalya, N. T., \& Anjani, S. R. (2020). MANAJEMEN

\section{GURU DALAM KUALITAS \\ MENDIDIK SEBAGAI UPAYA PENINGKATAN MUTU SUMBER DAYA MANUSIA. JURNAL LOKABMAS KREATIF, 1(2), 52-55.}

Pasaribu, V. L. D., Agrasadya, A., Shabrina, N., \& Krisnaldy, K. (2020). Menjadi Enterpreneur Muda Yang Memiliki Jiwa Leadership Untuk Menghadapi Masa Depan. Abdi Laksana: Jurnal Pengabdian Kepada Masyarakat, 1(1).

Pasaribu, V. L. D., Susanti, F., \& Hartuti, E. T. K. (2019). Memotivasi Siswa dan Siswi SMK Letris Indonesia di Dalam Menentukan Pilihan Untuk Melanjutkan Pendidikan Atau Bekerja Setelah Lulus Sekolah. Jurnal Pengabdian Dharma Laksana, 1(2), 161-172.

Pasaribu, V. L. D., Sulaiman, S., Sutiman, S., Thaharudin, T., \& Purnomo, B. Y. (2020). Pengenalan Letak Posyandu Terdekat Dikelurahan Pisangan Dengan Manajemen Pemasaran Revolusi 4.0 Untuk Meningkatkan Pengetahuan Masyarakat Letak Dan Fungsi Posyandu Terdekat Pada Kelurahan Pisangan. Dedikasi Pkm, 1(1), 105-110.

Pasaribu, V. L. D., Oktrima, B., Prabowo, B., Arianto, N., \& Haryoko, U. B. (2020). Progam Pendampingan Dan Penyelenggaraan Pendidikan Anak Pada Usia Dini Terhadap Prestasi Belajar Dilingkungan Rt 020 Rw 009. Kel Giri Peni. Kec Wates. Yogyakarta. Jurnal Lokabmas Kreatif, 1(1), 71-75. 
Loyalitas Kreativitas

Abdi Masyarakat Kreatif
P-ISSN 2722-2101, E-ISSN 2722-4201

Program Studi Ekonomi Manajemen Universitas Pamulang Jurnal LOKABMAS Kreatif Vol.02,No.02.Juli 2021 Hal.107-114

Email:jurnalkreatif.manajemen@gmail.com
Pasaribu, V. L. D., Jannah, M., Fazar, M., Putra, S. P., Monalisa, M., \& Sofa, M. (2021). MENINGKATKAN PRODUKTIVITAS USAHA DIMASA PANDEMI PADA IBU PKK RT 004/003 KELURAHAN SAWAH BARU CIPUTAT, TANGERANG SELATAN. Abdi Laksana: Jurnal Pengabdian Kepada Masyarakat, 2(2), 295-301.

Pasaribu, V. L. D., Yuniati, H. L., Pranata, R., Sembayu, R., Purba, S. M., \& Nurbayani, T. T. A. (2021). MANAJEMEN KEUANGAN UNTUK MENGHADAPI DAN BERTAHAN DI ERA COVID 19. Jurnal Abdimas Tri Dharma Manajemen, 2(2), 12-18.

Pasaribu, V. L. D., Dwiyatni, A., Sabina, C., Ridwan, M., Gunawan, D. D., \& Noviani, B. C. (2021). EVALUASI PENERAPAN $3 \mathrm{M}$ DIMASA PANDEMIC COVID 19. Jurnal Abdimas Tri Dharma Manajemen, 2(2), 54-60.

Pasaribu, V. L. D., Syafei, A. N., Farhan, A., Aufaizah, A., Irani, C., \& Firtiayani, S. R. (2021). PENGARUH DISPLIN PROTOKOL KESEHATAN TERHADAP PENCEGAHAN PENULARAN VIRUS COVID19. Jurnal Abdimas Tri Dharma Manajemen, 2(2), 91-98.

\section{DOKUMENTASI FOTO KEGIATAN}

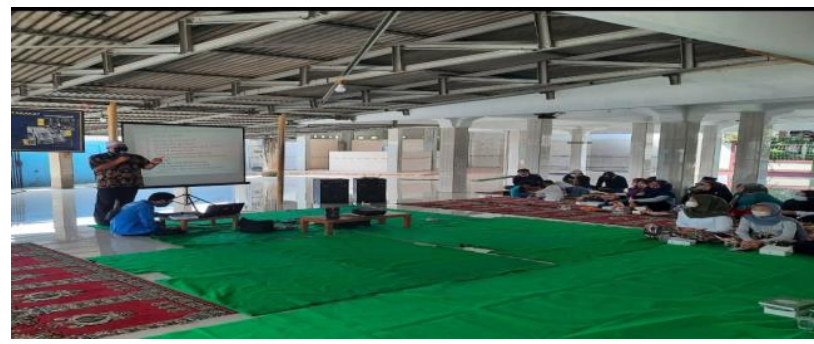

Materi yang sampaikan oleh Dosen Unpam

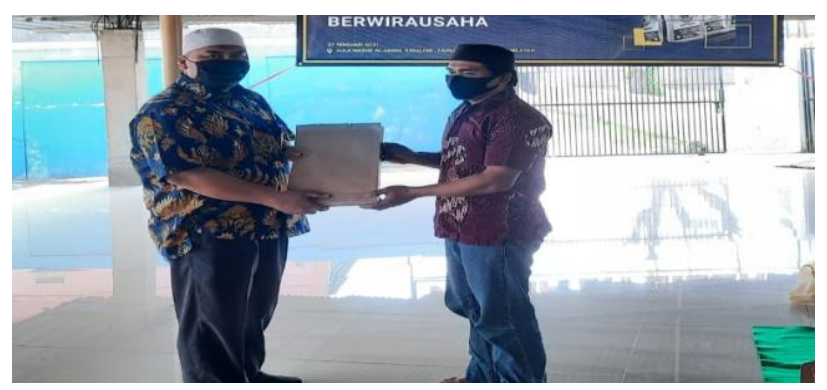

Penyerahan kenang-kenangan

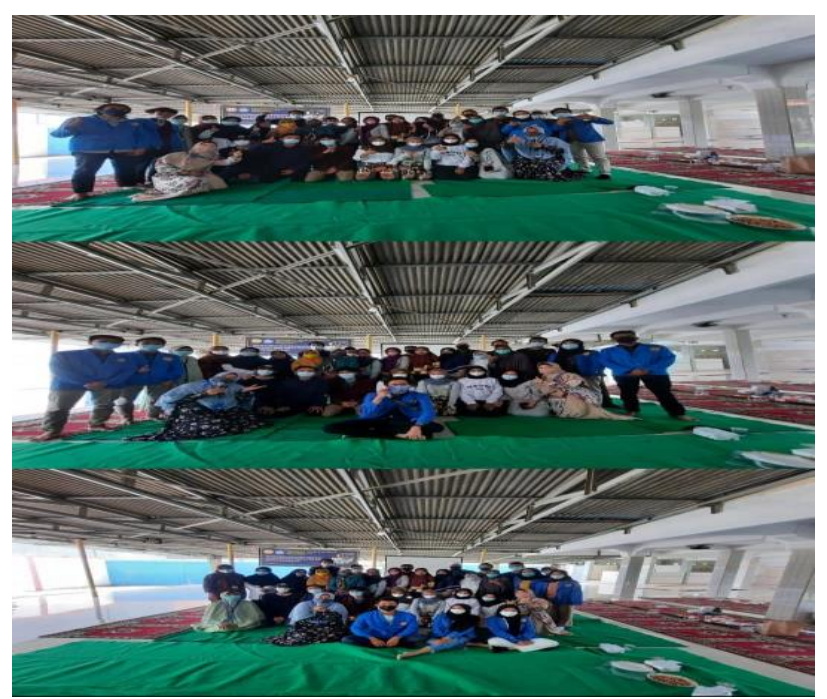

Peserta PKM dan Tim Dosen Unpam 